\title{
Regulation of the Production of Hemicellulolytic and Cellulolytic Enzymes by a Streptomyces sp. Growing on Lignocellulose
}

\author{
By BERNARD GODDEN, THIERRY LEGON, PIERRE HELVENSTEIN \\ AND MICHEL PENNINCKX* \\ Laboratoire de Microbiologie, Faculté des Sciences, Université Libre de Bruxelles, c/o Institut de \\ Recherches du CERIA, 1, avenue Emile Gryson, B-1070 Brussels, Belgium
}

(Received 27 June 1988; revised 20 September 1988; accepted 14 October 1988)

\begin{abstract}
A Streptomyces sp. isolated from compost degraded the hemicellulose fraction of straw efficiently but apparently not native cellulose. Ball-milled straw induced endoglucanase, $\beta$-glucosidase, $\beta$-xylanase and $\beta$-xylosidase. Carboxymethylcellulose, cellotetraose and cellotriose induced cellulolytic enzymes specifically whereas cellobiose acted as inducer for $\beta$-glucosidase only. Cellotriose and cellotetraose induced $\beta$-glucosidase, but only partially induced endoglucanase. Hemicellulose (in the form of xylan) and xylobiose induced only $\beta$-xylanase and $\beta$-xylosidase. Kraft lignin and syringic acid induced $\beta$-xylanase and endoglucanase but not the other enzymes. 3,4-Dimethoxycinnamic acid slightly induced $\beta$-xylanase whereas 3,5-dimethoxy-4-hydroxycinnamic acid specifically induced endoglucanase. Neither veratric acid nor vanillic and ferulic acids induced any of the cellulolytic or hemicellulolytic enzymes. Enzyme production was subject to a form of carbon catabolite repression. Endoglucanase and $\beta$-xylanase were excreted into the culture medium. Four protein components, one acidic (pI 5.2) and three basic (pI 8.15, 8.45 and 8.65) exhibited $\beta$-xylanase activity. Two acidic components (pI 3.55 and 3.75 ) displayed endoglucanase activity.
\end{abstract}

\section{INTRODUCTION}

Actinomycetes play a considerable role in recycling nutrients in natural and man-made environments. For example, they are thought to be involved in the primary degradation of organic matter in compost and related materials (Goodfellow \& Williams, 1983). Lignocellulosedegrading actinomycetes have been isolated from compost but little is known about their growth pattern and control of lignocellulolytic enzyme synthesis (McCarthy, 1987). Previous work has shown the potential of actinomycetes isolated from agricultural and garden compost to degrade cellulose (Godden \& Penninckx, 1984; Van Zyl, 1985). Detailed knowledge of the physiological requirements of enzyme production is a prerequisite for efficient future exploitation of actinomycetes in lignocellulose bioconversion.

Here we report a physiological study of a strain of Streptomyces isolated from cattle manure compost (Godden \& Penninckx, 1984). This strain is an efficient hemicellulose-degrading organism. It also produces a cellulolytic enzyme and was thus chosen as a model for evaluating factors governing the synthesis of both cellulose- and hemicellulose-degrading enzymes. We also used ball-milled wheat straw as a realistic lignocellulose substrate which might be used in bioconversion.

\section{METHODS}

Organism and culture conditions. The Streptomyces sp., strain EC1, was isolated from cattle manure compost (Godden \& Penninckx, 1984). It is mesophilic. This strain was selected for study on the basis of its ability, in an initial screening, to produce straw-saccharifying enzymes (Ball \& McCarthy, 1988). It was maintained either

Abbreviations: CMC, carboxymethylcellulose; DNS, dinitrosalicylic acid; RBR, remazol brilliant blue $\mathbf{R}$. 
frozen at $-80^{\circ} \mathrm{C}$ in $80 \%(w / v)$ glycerol or at $4{ }^{\circ} \mathrm{C}$ as one-week-old slant cultures on Difco actinomycetes isolation agar. Spore suspensions prepared from such slants (Hopwood et al., 1985) were resuspended in $0.9 \% \mathrm{NaCl}$ and used for inoculation of the experimental media. The basal medium contained $2 \mathrm{~g}\left(\mathrm{NH}_{4}\right)_{2} \mathrm{SO}_{4}, 0 \cdot 2 \mathrm{~g} \mathrm{MgCl}_{2} \cdot 6 \mathrm{H}_{2} \mathrm{O}$, $11 \mathrm{mg} \mathrm{CaCl}, 2 \mathrm{~g} \mathrm{~K}_{2} \mathrm{HPO}_{4}$ and $0.6 \mathrm{~g} \mathrm{KH}_{2} \mathrm{PO}_{4}$ per litre of distilled water, final $\mathrm{pH} \mathrm{7.5}$; it was sterilized for $15 \mathrm{~min}$ at $121^{\circ} \mathrm{C}$. Before adding the carbon source, each litre of cooled medium $\left(50^{\circ} \mathrm{C}\right)$ was supplemented with $20 \mathrm{ml}$ of a vitamin solution (Malfait et al., 1984). The carbon source was added as indicated in the text. The substrates were sterilized by filtration except xylan and straw, which were sterilized for $15 \mathrm{~min}$ at $121^{\circ} \mathrm{C}$.

In order to ensure aerobic conditions, the volume of the medium was restricted to $1 / 5$ of the total volume of each flask. A stainless steel spring was inserted into the flask to favour dispersed growth in an orbital incubation shaker (154 strokes $\left.\min ^{-1}\right)$. Cultures were grown at $37^{\circ} \mathrm{C}$.

In the growth experiments, about $10 \mathrm{mg}$ dry weight of pregerminated spores in $30 \mathrm{ml}$ was inoculated into $300 \mathrm{ml}$ of medium containing the desired carbon source. After $48 \mathrm{~h}$ of growth, this preculture was added to 31 of fresh medium containing the same carbon source. Samples ( $100 \mathrm{ml}$ culture medium) were taken and analysed as indicated in the text.

In induction experiments, $20 \mathrm{ml}$ of spore suspension (10 mg dry weight) was first inoculated into $200 \mathrm{ml}$ of a culture medium containing $0.2 \%$ glycerol as the carbon source. After $48 \mathrm{~h}$ of growth, the cells were harvested by filtration on a Millipore $0.45 \mu \mathrm{m}$ membrane under sterile conditions, and inoculated into $400 \mathrm{ml}$ of the induction medium being tested.

Cellotriose and cellotetraose were a gift from Dr M. Clayssens, University of Ghent, Belgium. Kraft lignin was obtained from Dr A. Ball, University of Liverpool, UK.

Enzyme determination. The sample of culture medium to be analysed was first centrifuged at $27000 \mathrm{~g}$ for $10 \mathrm{~min}$. The pellet was resuspended in $3 \mathrm{ml} 10 \mathrm{~mm}$-potassium phosphate $\mathrm{pH} 7.0$ and sonicated with cooling at $4{ }^{\circ} \mathrm{C}$ for 10 min with a Vibra Cell VC 500 ultrasonic processor (Sonics Materials). The suspension obtained was clarified by centrifugation at $27000 \mathrm{~g}$ for $10 \mathrm{~min}$ and the supernatant (i.e. crude extract of the bacteria) used for the assay of $\beta$-glucosidase (EC 3.2.1.21) and $\beta$-xylosidase (EC 3.2.1.37).

$\beta$-Xylanase (EC 3.2.1.8) and endoglucanase (EC 3.2.1.4) were assayed in the supernatant from the first centrifugation (i.e. culture medium).

In growth experiments where sugars could interfere with the enzyme assays, these were first removed by chromatography on a calibrated Biogel P2 column. The conditions of enzyme assay ( $\mathrm{pH}$, temperature, substrate concentration, incubation time) were optimized in preliminary experiments. Rate of product release was linear with time for up to $2 \mathrm{~h}$ with appropriately diluted samples, indicating that the enzymes were stable in the conditions used throughout this work. Incubation times ranged from $15 \mathrm{~min}$ to $1 \mathrm{~h}$ depending on the activity of the sample.

$\beta$-Glucosidase and $\beta$-xylosidase assays were based on release of $p$-nitrophenol from $p$-nitrophenyl $\beta$-D-glucopyranoside (Ferchak \& Pye, 1983) and $p$-nitrophenyl $\beta$-D-xylopyranoside (Sigma) (Biely et al., 1980) respectively. Appropriately diluted samples were incubated with $20 \mathrm{mM}$-substrate in the presence of $50 \mathrm{~mm}$ potassium phosphate $\mathrm{pH} 6.5$ at $50^{\circ} \mathrm{C}$. The reaction was stopped by addition of $100 \mathrm{mM}-\mathrm{NaOH} / \mathrm{glycine} \mathrm{pH} 10.9$. Absorbance of the liberated $p$-nitrophenol was measured at $425 \mathrm{~nm}$. Activity units (U) for $\beta$-glucosidase and $\beta$-xylosidase are $\mu \mathrm{mol} p$-nitrophenol produced $\mathrm{min}^{-1}$.

$\beta$-Xylanase was assayed at $50^{\circ} \mathrm{C}$ by incubating $1 \mathrm{ml}$ of enzyme solution with $1 \mathrm{ml} 100 \mathrm{~mm}$-potassium phosphate $\mathrm{pH} 8.0$ containing $1 \%(\mathrm{w} / \mathrm{v})$ oat spelt xylan (Sigma). The amount of reducing sugars released was determined by the dinitrosalicylic acid (DNS) method of Miller (1959) with D-xylose as standard. Units of $\beta$-xylanase activity (U) are $\mu \mathrm{mol}$ reducing sugars produced $\mathrm{min}^{-1}$.

The activity of endoglucanase was determined at $50^{\circ} \mathrm{C}$ by adding $1 \mathrm{ml}$ of enzyme solution to $1 \mathrm{ml} 100 \mathrm{mM}$ potassium phosphate $\mathrm{pH} 8.0$ containing $1 \%(\mathrm{w} / \mathrm{v})$ carboxymethylcellulose (CMC; Koch-Light 600$)$. The amount of reducing sugars in terms of glucose equivalents was determined either by the DNS procedure mentioned above, or, when high sensitivity was required, by the method of Halliwell \& Lovelady (1981). Units of endoglucanase activity (U) are $\mu \mathrm{mol}$ reducing sugars produced $\mathrm{min}^{-1}$.

Growth measurements. During the growth and induction experiments, the production of cell biomass was determined indirectly by estimation of total nitrogen in the solids from the culture using the Kjeldahl procedure (Buchi apparatus). Bacterial protein was calculated as $\mathbf{N} \times 6 \cdot 25$.

A conversion factor between cellular nitrogen and dry weight was determined for cells of the Streptomyces $\mathrm{sp}$. grown on CMC and soluble xylan for $48 \mathrm{~h}$. The culture was divided into two parts and filtered on Millipore membranes $(0.45 \mu \mathrm{m})$. One part served for determination of cellular nitrogen as described above. The other was used for determination of dry weight on pre-weighed membranes, washed twice with water and dried at $105^{\circ} \mathrm{C}$ to constant weight (about $48 \mathrm{~h}$ ). From three independent measurements, $1 \mathrm{mg}$ of cellular nitrogen was equivalent to $13.8 \pm 0.15 \mathrm{mg}$ dry weight (mean \pm range about the mean). This mean value was used for the estimation of growth yield.

Estimation of cellulose and hemicellulose in cultures. A sample of the culture on straw corresponding to about 
$30 \mathrm{mg}$ material was filtered on a Millipore $0.45 \mu \mathrm{m}$ membrane. The residue on the filter was transferred to a vessel containing $90 \mathrm{ml} 0.5 \mathrm{M}-\mathrm{H}_{2} \mathrm{SO}_{4}$, incubated for $12 \mathrm{~h}$ at $90^{\circ} \mathrm{C}$ and filtered on a Whatman GFA filter.

Total sugars thus released by hemicellulose hydrolysis were estimated in the filtrate by the method of Dubois $e t$ al. (1956). The value was converted to hemicellulose using a standard obtained with straw hemicellulose prepared according to De Stevens (1957). Cellulose was estimated on the Whatman GFA filters by the procedure of Updegraaf (1969). CMC and xylan were estimated in the culture according to Dubois et al. (1956).

Preparation of xylobiose. Xylobiose was obtained by enzymic hydrolysis of oat spelt xylan (Sigma) using crude $\beta$-xylanase from the Streptomyces $\mathrm{sp}$. The reaction was performed for $12 \mathrm{~h}$ at ambient temperature in a dialysis bag. The diffusible fraction was concentrated in vacuo at $45^{\circ} \mathrm{C}$ and chromatographed on an activated charcoal (Darco G.60-Aldrich) column $(2.5 \times 35 \mathrm{~cm})$ conditioned with water. The column was eluted with $5 \%(\mathrm{v} / \mathrm{v})$ ethanol. Carbohydrates in the effluent were detected by the DNS method (Miller, 1959). Fractions containing only xylobiose were identified by high-performance liquid chromatography (HPLC) (Bernier et al., 1983) and pooled. After evaporation, xylobiose was crystallized from aqueous methanol and its identity confirmed by HPLC.

Isoelectrofocusing $(I E F)$. Endoglucanase and $\beta$-xylanase activities were detected in culture supernatants by IEF, using the Phast-system of Pharmacia. $\beta$-Xylanase activity was detected by the replica gel procedure (Biely $e t$ al., $1985 a, b)$. Endoglucanase activity was detected by a similar procedure using replica gels with $1 \%(\mathrm{w} / \mathrm{v}) \mathrm{CMC}$ in 100 mM-potassium phosphate pH 8.0. Congo Red (Theater \& Wood, 1982) was used to reveal the undigested substrate. RBR-xylan was purchased from Sigma. Protein bands were revealed by silver staining (Pharmacia Phast-system Manual).

\section{RESULTS}

Growth curves and enzyme production by the Streptomyces $s p$.

Fig. $1(a)$ shows the growth curve of the strain on $0.2 \%$ ball-milled straw. The stationary phase was attained after about $48 \mathrm{~h}$. A similar pattern of growth was observed with other carbon sources and at concentrations ranging from $0 \cdot 2$ to $1 \%(\mathrm{w} / \mathrm{v})$ (not illustrated). As only about $10 \%$ of the nitrogen source was consumed by the time growth ceased in the presence of $1 \%(\mathrm{w} / \mathrm{v})$ carbon source, these cultures were not nitrogen or carbon limited. Presumably growth stopped because of the production of inhibitory metabolite(s) and/or exhaustion of a micronutrient.

At the stationary phase of cultures with $1 \%(\mathrm{w} / \mathrm{v}) \mathrm{CMC}$ or xylan as sole carbon source, the CMC and xylan content was reduced by 69 and $24 \%$, respectively. This corresponded to respective growth yields of 0.48 and $0.49 \mathrm{~g}$ microbial dry weight per $\mathrm{g}$ CMC and xylan consumed. Some $40 \%$ of the hemicellulose but only $5 \%$ of the cellulose fraction of ball-milled straw was consumed during the growth phase of the Streptomyces sp. (Fig. 1a), corresponding to a growth yield of $0.51 \mathrm{~g}$ dry weight per $\mathrm{g}$ straw consumed. A decrease in cellular protein was observed after $48 \mathrm{~h}$ of growth (Fig. $1 \mathrm{a}$ ). This probably resulted from cellular lysis: a large proportion of 3-d-old cells no longer retained the Gram stain.

$\beta$-Glucosidase and $\beta$-xylosidase activities, which were associated with the bacterial cells, rose rapidly during the first $24 \mathrm{~h}$ of culture but later declined sharply (Fig. 1 b). $\beta$-Xylanase and endoglucanase (for which $>95 \%$ activity was detected in the culture supernatant) behaved differently: endoglucanase activity increased throughout the $3 \mathrm{~d}$ of the experiment, while $\beta$-xylanase increased to a stable plateau value in $1-2 \mathrm{~d}$ (Fig. $1 b$ ).

When the Streptomyces sp. was grown on a range of carbon sources (results not shown in detail), high activities of xylanolytic enzymes were found only on xylobiose, xylan and straw; endoglucanase was present at high activity only on straw, and surprisingly not $(<10 \%$ of the specific activity on straw) on CMC, a model cellulose. In contrast, $\beta$-glucosidase was expressed at high activities on cellobiose and straw. Low activities (i.e. $<10 \%$ of the maximal values) were detected on monosaccharide carbon sources (glucose, fructose, mannose, xylose, D-arabinose and rhamnose), while none of the enzyme activities were detected on glycerol as a carbon source.

Expression of enzyme activities in relation to the carbon source was studied in more detail by examining the kinetics of induction-repression, using cells grown on glycerol to inoculate media containing various carbon sources.

\section{Induction and repression pattern}

Fig. 2 shows enzyme induction patterns with polymeric substrates and the dimers cellobiose and xylobiose. The enzymes of xylan degradation were apparently induced by straw, xylan or 


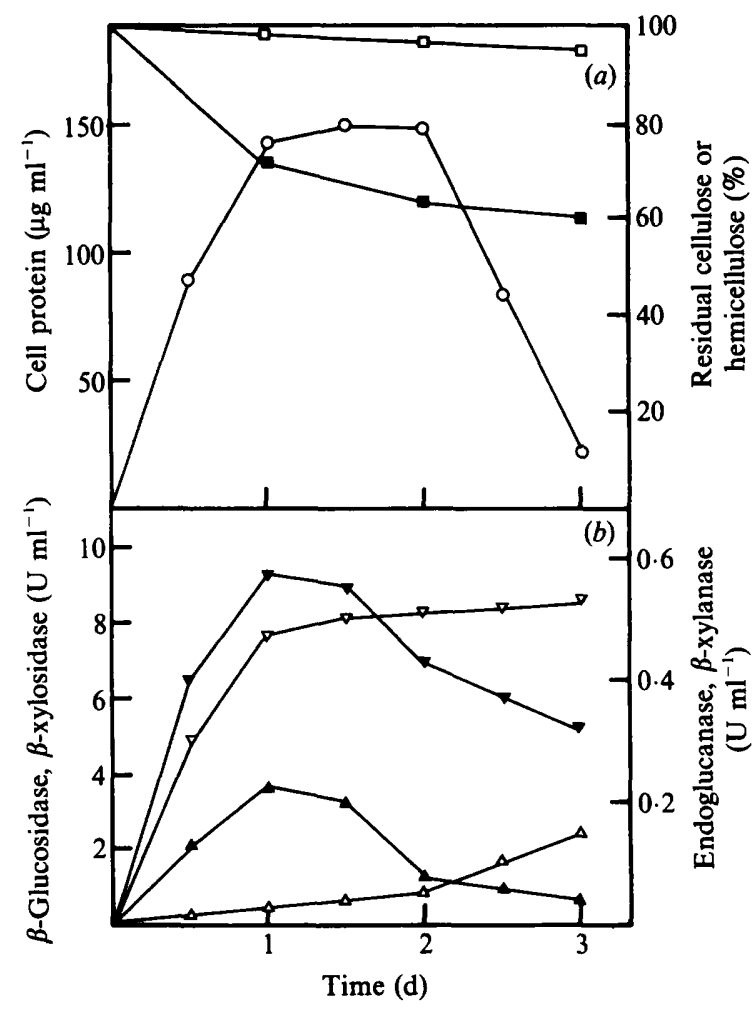

Fig. 1. Growth and enzyme production of Streptomyces sp. on $0.2 \%$ ball-milled straw. (a) Cell protein $(0)$, and percentage of residual cellulose $(\square)$ and residual hemicellulose $(\square)$. (b) Enzyme production: $\beta$ glucosidase $(\boldsymbol{\Delta})$, endoglucanase $(\Delta), \beta$-xylosidase $(\nabla)$ and $\beta$-xylanase $(\nabla)$. Standard deviations were all within $10 \%$ of the mean values presented (three independent assays).

\section{Table 1. Enzyme induction in Streptomyces sp. and effect of glycerol}

Enzyme activities were induced for $24 \mathrm{~h}$ with $0.2 \%$ substrate in the absence or (where shown) in the presence of $0.2 \%$ glycerol as described in Methods. All enzyme activities are expressed as $U$ (mg protein) ${ }^{-1}$; bacterial protein was determined by Kjeldahl analysis of total $\mathbf{N}$ (see Methods). Experiments were done in triplicate; data are mean \pm range about the mean. ND, Not detectable.

\section{Substrate}

Glycerol

Straw

Straw + glycerol

CMC

CMC + glycerol

Xylan

Xylan + glycerol

Glucose

Fructose

Mannose

Xylose

D-Arabinose

Cellobiose

Xylobiose

Kraft lignin

Syringic acid

3,4-Dimethoxycinnamic acid

3,5-Dimethoxy-4-hydroxycinnamic acid

Veratric acid

Vanillic acid

Ferulic acid

$\begin{array}{cc}\beta \text {-Glucosidase } & \text { Endoglucanase } \\ \text { ND } & \text { ND } \\ 8.7 \pm 0.4 & 1.6 \pm 0.12 \\ 3.2 \pm 0.2 & 0.63 \pm 0.03 \\ 9.1 \pm 0.8 & 1.4 \pm 0.1 \\ 1.3 \pm 0.05 & 0.2 \pm 0.03 \\ 1.6 \pm 0.07 & 0.12 \pm 0.01 \\ \text { ND } & 0.06 \pm 0.01 \\ \text { ND } & 0.04 \pm 0.01 \\ 0.25 \pm 0.02 & 0.06 \pm 0.01 \\ 0.4 \pm 0.05 & 0.12 \pm 0.02 \\ \text { ND } & 0.15 \pm 0.02 \\ 0.02 \pm 0.01 & 0.04 \pm 0.01 \\ 12.6 \pm 0.6 & 0.10 \pm 0.02 \\ 0.7 \pm 0.06 & 0.10 \pm 0.02 \\ \text { ND } & 0.87 \pm 0.05 \\ \text { ND } & 0.62 \pm 0.01 \\ \text { ND } & \text { ND } \\ \text { ND } & 1.40 \pm 0.07 \\ \text { ND } & \text { ND } \\ \text { ND } & \text { ND } \\ \text { ND } & 0.03 \pm 0.01\end{array}$

$\beta$-Xylosidase

$\beta$-Xylanase

\begin{tabular}{|c|c|}
\hline ND & ND \\
\hline $245 \cdot 0 \pm 0.7$ & $5.2 \pm 0.2$ \\
\hline $19.4 \pm 0.6$ & $1.2 \pm 0.1$ \\
\hline $3.3 \pm 0.3$ & $1 \cdot 3 \pm 0.1$ \\
\hline ND & $0.6 \pm 0.07$ \\
\hline $232 \cdot 0 \pm 5$ & $4.7 \pm 0.4$ \\
\hline $61.4 \pm 1.3$ & $2.4 \pm 0.17$ \\
\hline ND & $0.4 \pm 0.05$ \\
\hline ND & $0.29 \pm 0.03$ \\
\hline ND & $0.41 \pm 0.04$ \\
\hline ND & $0.6 \pm 0.04$ \\
\hline ND & $0.13 \pm 0.02$ \\
\hline $0.7 \pm 0.03$ & $0.14 \pm 0.03$ \\
\hline $280 \cdot 0 \pm 7$ & $5 \cdot 3 \pm 0.1$ \\
\hline $1.1 \pm 0.02$ & $4.6 \pm 0.2$ \\
\hline $4 \cdot 1 \pm 0 \cdot 3$ & $9.8 \pm 0.3$ \\
\hline $2.4 \pm 0.18$ & $1.8 \pm 0.1$ \\
\hline ND & $0.15 \pm 0.02$ \\
\hline ND & ND \\
\hline ND & ND \\
\hline ND & ND \\
\hline
\end{tabular}




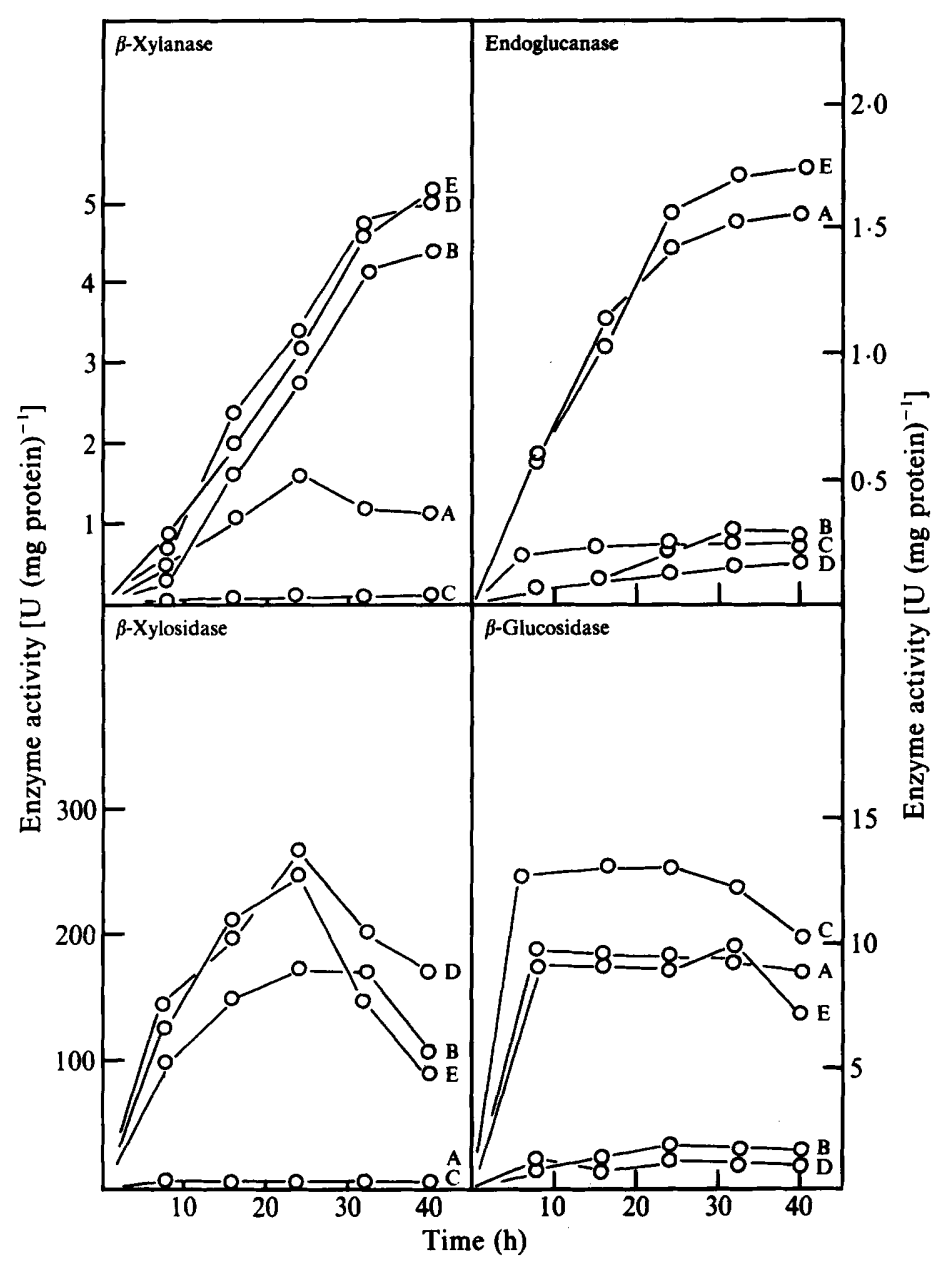

Fig. 2. Enzyme induction in Streptomyces sp. on different carbon sources. A, CMC; B, xylan; C, cellobiose; D, xylobiose; E, straw. Standard deviations were all within $10 \%$ of the mean values presented (three independent assays).

xylobiose. $\beta$-Xylosidase was not induced by $\mathrm{CMC}$, and $\beta$-xylanase was poorly induced by this carbon source. When induced on xylan, straw or xylobiose, $\beta$-xylosidase attained maximal values $20-30 \mathrm{~h}$ after transfer from the glycerol medium and declined thereafter. This pattern was not observed for $\beta$-xylanase activity, which attained a plateau level. A decline in $\beta$-xylosidase activity was also observed in the growth experiments on straw (Fig. 1b).

Endoglucanase and $\beta$-glucosidase, enzymes of cellulose degradation, were induced on CMC and straw but only weakly on xylan or xylobiose. Endoglucanase attained a much higher specific activity in induction experiments on CMC than in growing cultures. Cellobiose was a poor inducer for endoglucanase, which was expressed at a slightly higher level than on straw or CMC, but it did induce $\beta$-glucosidase (Table 1). Cellotriose and cellotetraose induced $\beta$-glucosidase and partially induced endoglucanase (Fig. 3), but did not induce the xylanolytic enzymes (not illustrated). Little or no induction of any of the four enzymes occurred when cells were grown on sugar residues found in lignocellulose: glucose, fructose, mannose, xylose and D-arabinose (Table 1).

Slight differences between the values obtained with the different sugars (Table 1) could be attributed to minimizing catabolite repression. Kraft lignin, chosen as a model lignin, induced 


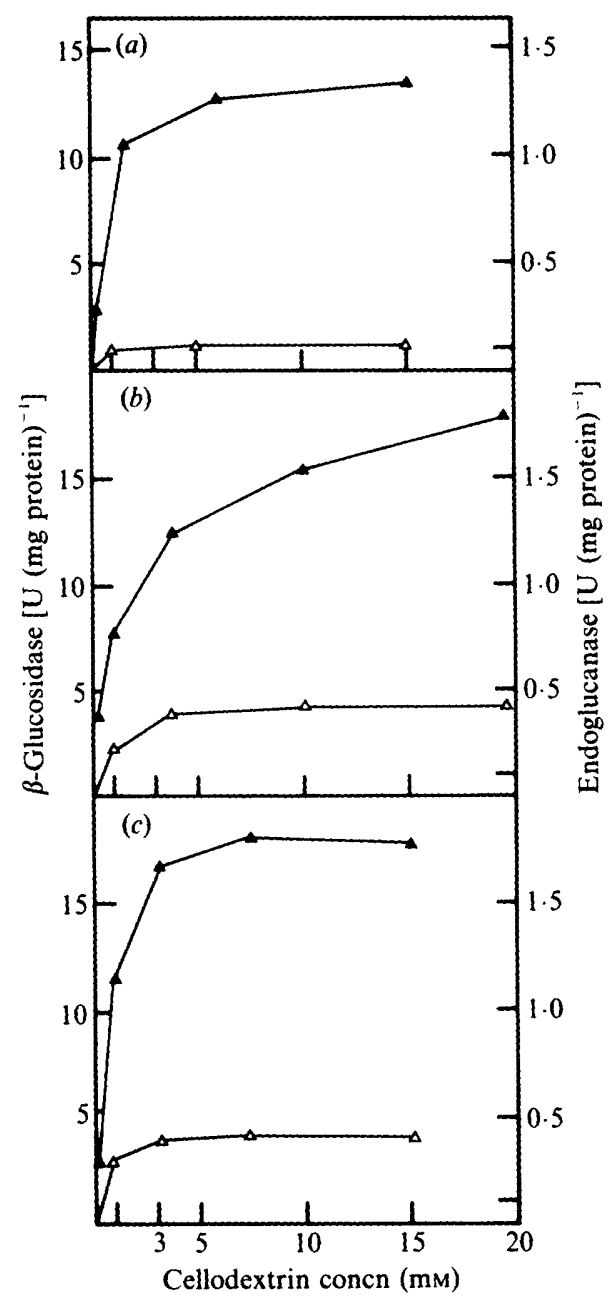

Fig. 3. Effect of cellodextrins on enzyme induction in Streptomyces sp. Cells from preculture on glycerol were induced for $24 \mathrm{~h}$ in the presence of different concentrations of cellodextrins: $(a)$ cellobiose; $(b)$ cellotriose; $(c)$ cellotetraose. $\Delta, \beta$-Glucosidase; $\Delta$, endoglucanase. Standard deviations were all within $10 \%$ of the mean values presented (three independent assays).

endoglucanase and $\beta$-xylanase but apparently not $\beta$-glucosidase or $\beta$-xylosidase (Table 1 ). Products putatively derived from lignin degradation (Flaigl et al., 1975), were also tested as inducers (Table 1). Syringic acid had apparently the same effect as Kraft lignin. 3,4-Dimethoxycinnamic acid partially induced $\beta$-xylanase, whereas endoglucanase was the only enzyme induced by 3,5-dimethoxy-4-hydroxycinnamic acid. When glycerol was present in the inducing media (Table 1), the specific enzyme activities attained after $48 \mathrm{~h}$ were lower than in the media not supplemented with glycerol. This effect is consistent with a form of carbon catabolite repression effect mediated by glycerol. Furthermore, enzyme induction was prevented by $50 \mu \mathrm{g}$ chloramphenicol ml $\mathrm{m}^{-1}$ (not illustrated), indicating that enzyme induction in the Streptomyces sp. was likely to be de novo synthesis.

\section{Enzyme components in culture filtrates of the Streptomyces sp.}

IEF was performed on the supernatants of induction media (Fig. 4). During induction on CMC, only acidic proteins were secreted. Among the three protein bands revealed by silver staining, two (pI 3.55 and 3.75) displayed endoglucanase activity. Cellulase activities were 


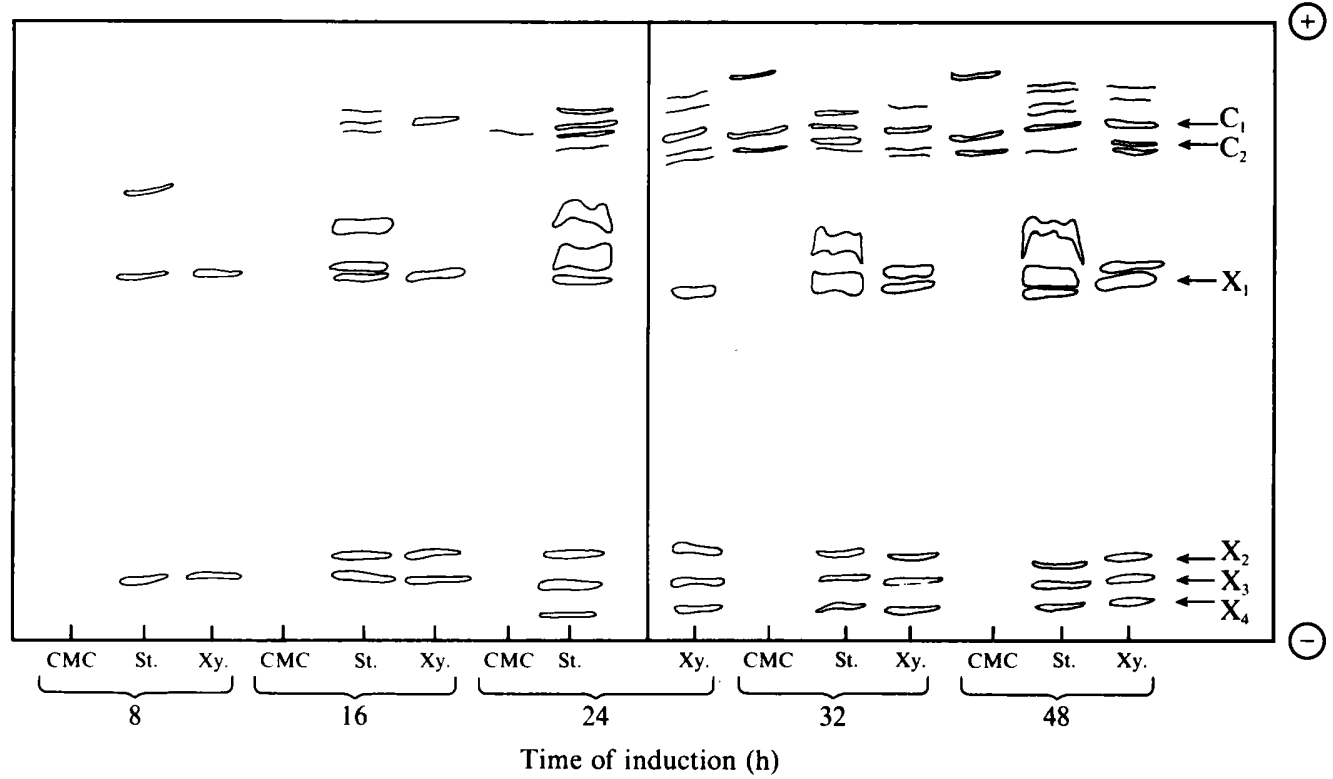

Fig. 4. IEF analysis of the supernatants of induction media. The bands shown are silver-stained proteins. The arrows indicate the different enzyme activities detected on a parallel gel stained for activity: $C_{1}, C_{2}$, endoglucanases; $X_{1}, X_{2}, X_{3}, X_{4}, \beta$-xylanases. Inducers: CMC, straw (St.) and xylan (Xy.).

detectable on straw, and also on xylan. IEF showed that acidic and basic proteins were present in culture fluids of the Streptomyces sp. grown on xylan or straw. Four $\beta$-xylanase activities (pI 5.2, 8.15, 8.45 and 8.65) were detected (Fig. 4). The acidic component (pI 5.20) was synthesized first, followed successively by the pI $8 \cdot 45$, pI 8.15 and pI 8.65 components.

\section{DISCUSSION}

Our results show that at least four electrophoretically distinct $\beta$-xylanases and two endoglucanases are produced by this strain of Streptomyces $\mathrm{sp}$. The highest specific activities of xylanolytic and cellulolytic enzymes were observed on xylan and CMC respectively. Straw, however, induced the complete set of these enzymes, even though this strain does not appear to degrade the cellulose fraction of straw significantly. Furthermore, some lignin-derived compounds elicited the synthesis of endoglucanase and $\beta$-xylanase in this Streptomyces $\mathrm{sp}$. This strain is also able to use Kraft lignin and compounds derived from native lignin as sole carbon sources but growth rates and yields are very different (B. Godden, P. Helvenstein \& M. Penninckx, unpublished results). Cellotriose and cellotetraose partially induced endoglucanase, and, as fragments derived from cellulose, these molecules may be responsible for the weak induction of endoglucanase observed in batch culture with CMC. High cellulase specific activities in cultures growing on a natural cellulose-containing substrate like straw might result from co-operation between various inducers derived from the components of the lignocellulose complex.

Kluepfel and coworkers (Kluepfel \& Ishaque, 1982; Kluepfel et al., 1986) have suggested a possible inducing effect of xylan on endoglucanase in certain Streptomyces strains. The rapid degradation of xylan by these strains might, however, explain improved production of endoglucanase in cultures containing xylan. In the present work, where we have expressed the induction data in terms of specific enzyme activities, the specific activity of endoglucanase determined on xylan was only about $27 \%$ of the value observed on straw.

In conclusion, it appears that the different component enzymes of lignocellulose degradation 
in this strain of Streptomyces sp. are subject to distinct controls, with the possibility of some cross-regulation. The low level of cellulase activity against natural cellulose deserves further attention, although it may be that this type of Streptomyces must co-operate with other microorganisms in compost to degrade native straw cellulose completely and efficiently.

This work was supported by the Commission of the European Communities.

\section{REFERENCES}

Ball, A. S. \& MCCARTHY, A. J. (1988). Saccharification of straw by actinomycete enzymes. Journal of General Microbiology 134, 2139-2147.

Bernier, R., JR, Desrochers, M., Jurasek, L. \& PAICE, M. G. (1983). Isolation and characterization of a xylanase from Bacillus subtilis. Applied and Environmental Microbiology 46, 511-514.

Biely, P., Vrsanska, A. \& Kratky, Z. (1980). Xylan degrading enzymes of the yeast Cryptococcus albidus. European Journal of Biochemistry 108, 313-321.

Biely, P., Mislovicova, D. \& Toman, R. (1985a). Soluble chromogenic substrates for the assay of endo-1,4- $\beta$-xylanases and endo-1,4- $\beta$-glucanases. Analytical Biochemistry 144, 142-146.

Biely, P., Markovic, O. \& Mislovicova, D. (1985b). Sensitive detection of endo-1,4- $\beta$-glucanases and endo-1,4- $\beta$-xylanases in gels. Analytical Biochemistry 144, 147-154.

De Stevens (1957). Preparation and properties of cellulose, hemicellulose and cellobiose. Methods in Enzymology 3, 31-35.

Dubois, M., Gilles, K. A., Hamilton, J. K., Rebers, P. A. \& SMith, F. (1956). Colorimetric methods for the determination of sugars and related substances. Analytical Chemistry 28, 350-356.

Ferchak, J. D. \& PYE, E. K. (1983). Effect of glucose and other sugars on the $\beta$-1,4-glucosidase of Thermonospora fusca. Biotechnology and Bioengineering 25, 2855-2864.

Flaigl, W., Bentelspaecher, H. \& Riets, E. (1975). Chemical composition and physical properties of humic substances. In Soil Components, vol. 1: Organic Components, pp. 1-211. Edited by J. E. Gieseking. Berlin: Springer-Verlag.

GodDEN, B. \& PENNINCKX, M. (1984). Identification and evolution of the cellulolytic microflora present during composting of cattle manure: on the role of Actinomyces sp. Annales de microbiologie 135B, 6978.

Goodfellow, M. \& Williams, S. T. (1983). Ecology of actinomycetes. Annual Review of Microbiology 126, 189-216.

Halliwell, G. \& Lovelady, J. (1981). Utilization of carboxymethylcellulose and enzyme synthesis by Trichoderma koningii. Journal of General Microbiology 126, 211-217.

Hopwood, D. A., BibB, M. J., Chater, K. F., Kieser, T., BRUTON, C. J., Kieser, H. M., LydiATE, D. J., Smith, C. P., WARD, J. M. \& SChrempF, H. (1985). Genetic Manipulation of Streptomyces, pp. 3-5. Norwich: John Innes Foundation.

KLUEPFEL, D. \& IshaQUE, M. (1982). Xylan induced cellulolytic enzymes in Streptomyces flavogriseus. Development Industrial Microbiology 23, 389-396.

Kluepfel, D., Shareck, F., Mondou, F. \& MoroSOLI, R. (1986). Characterization of cellulase and xylanase activities of Streptomyces lividans. Applied and Microbial Biotechnology 24, 230-234.

MCCARTHY, A. J. (1987). Lignocellulose degrading actinomycetes. FEMS Microbiology Reviews 46, 145 163.

Malfait, M., Godden, B. \& Penninckx, M. (1984). Growth and cellulase production of Micromonospora chalcae and Pseudonocardia thermophila. Annales de microbiologie 135B, 79-89.

Miller, G. L. (1959). Use of dinitrosalicylic acid reagent for determination of reducing sugar. Analytical Chemistry 31, 426-428.

Theater, R. M. \& WoOD, P. J. (1982). Use of Congo Red-polysaccharide interactions in enumeration and characterization of cellulolytic bacteria from the bovine rumen. Applied and Environmental Microbiology 43, 777-780.

UPDEGRAAF, D. M. (1969). Semi-micro determination of cellulose in biological materials. Analytical Chemistry 32, 420-424.

VAN ZYL, W. H. (1985). A study of the cellulase produced by three mesophilic actinomycetes grown on bagasse as substrate. Biotechnology and Bioengineering 27, 1367-1373. 